\title{
Insulin-mediated lipohypertrophy: an uncommon cause of diabetic ketoacidosis
}

\author{
Anjana Barola, ${ }^{1}$ Pramil Tiwari, ${ }^{1}$ Anil Bhansali ${ }^{2}$
}

'Department of Pharmacy Practice, National Institute of Pharmaceutical Education and Research (NIPER), S.A.S. Nagar (Mohali), Punjab, India 2Department of Endocrinology, Post Graduate Institute of Medical Education and Research, Chandigarh, India

\section{Correspondence to} Dr Anil Bhansali, anilbhansaliendocrine@gm ail.com

Accepted 9 June 2017
To cite: Barola A, Tiwari $P$, Bhansali A. BMJ Case Rep Published Online First: [please include Day Month Year]. doi:10.1136/bcr-2017 220387

\section{DESCRIPTION}

A 15 -year-old boy with a 3 -year history of type 1 diabetes mellitus was referred to endocrinology clinic for the management of uncontrolled blood glucose levels. His present treatment plan comprised subcutaneous basal-bolus insulin regimen. $\mathrm{He}$ was taking regular insulin before the three major meals and insulin glargine at the bedtime. His body mass index (BMI) was $14.8 \mathrm{~kg} / \mathrm{m}^{2}$ and $\mathrm{HbA} 1 \mathrm{c}$ level $14.9 \%$, suggesting uncontrolled hyperglycaemia for a long time.

On examination, he was found to have remarkably prominent bilateral lipohypertrophic areas on the lower abdomen (figure 1), large enough to be noticeable even through the clothing.

His injection practices revealed that he was self-administering insulin over the abdomen with the syringe of needle size $6 \mathrm{~mm}$, apparently leading to intramuscular injection in a thin-built person. ${ }^{1}$ Furthermore, he was drawing his recommended dose of basal insulin with the $40 \mathrm{IU} / \mathrm{mL}$ syringe out of a vial of $100 \mathrm{IU} / \mathrm{mL}$ strength resulting into 2.5 times of the prescribed amount. However, the match between insulin syringe and strength was appropriate for the bolus doses.

He was injecting in the area measured to be around $8.5 \times 5.5 \mathrm{~cm}$ on either side of the lower abdomen approximating the size of a credit card. He preferred this area, as injections at this site were painless. In addition, he was not performing systematic site rotation within a quadrant of abdominal area by leaving a space of $1 \mathrm{~cm}$ for the subsequent injections. Moreover, one syringe was reportedly used on an average six times. Missing the doses of insulin along with the habit of injecting into lipohypertrophic lesions caused one episode of diabetic

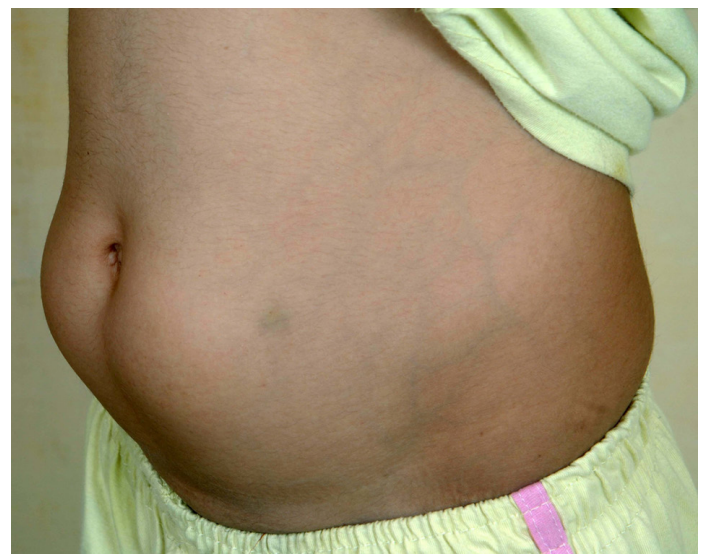

Figure 1 Showing prominent bulge on either side of the lower abdomen (side view).

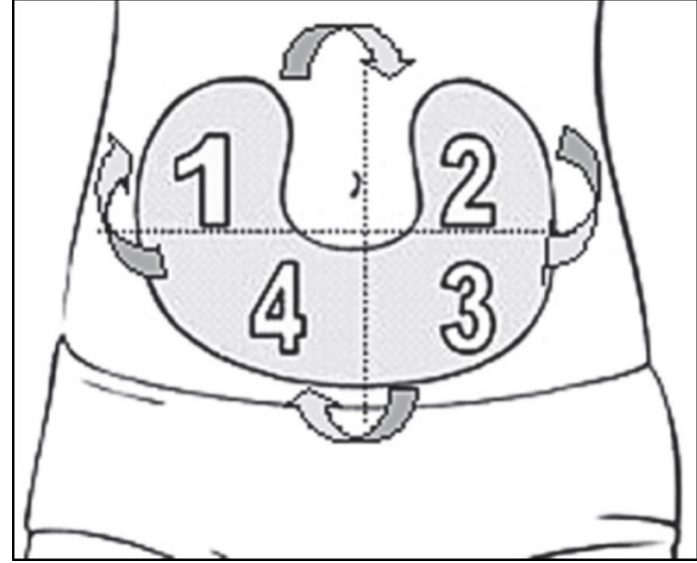

Figure 2 Illustration of systematic rotation scheme within abdominal quadrants. One quadrant per week in clockwise manner and then moving to the next quadrant. (Photographs courtesy of Lourdes Saez-de Ibarra and Ruth Gaspar, Diabetes Nurses and Specialist Educators from La Paz Hospital, Madrid, Spain.)

ketoacidosis requiring hospitalisation 2 weeks prior to this visit.

Patient was managed using talk, inspect and educate strategy followed by our endocrinology clinic considering the high prevalence of insulin-related lipohypertrophy in Indian patients. ${ }^{2}$ Readdressing correct injection technique is very important to curb lipohypertrophy and its consequences. Therefore, the systematic rotation (figure 2) and practice of injections in larger area were explained to the patient. He was also directed to discontinue injections into lipohypertrophic lesions and advised to inject into the normal tissue. It was further recommended to reduce the dose of insulin, guided by self-monitoring of blood glucose, for avoiding hypoglycaemia while shifting to normal site. Patient was educated about the importance of adhering to

\section{Learning points}

Create TIE (Talk, Inspect and Educate) with the patient

- Talk to the patients and their families regarding diabetes management to understand the ongoing challenges faced by them.

- Inspect the injection sites on regular basis for the early detection of lipohypertrophy.

- Educate the patients and their families about importance of proper insulin injection practice. 
insulin, appropriate match of insulin strength with syringe and single-time needle use. In view of the low BMI, he was switched to $4 \mathrm{~mm}$ needle size available for using with pen device. $^{1}$

Contributors Anjana Barola and Pramil Tiwari prepared the manuscript and helped in patient education. Anil Bhansali identified the case, edited the manuscript and guided the clinical management.

Competing interests None declared.

Patient consent Obtained.
Provenance and peer review Not commissioned; externally peer reviewed.

(c) BMJ Publishing Group Ltd (unless otherwise stated in the text of the article) 2017. All rights reserved. No commercial use is permitted unless otherwise expressly granted.

\section{REFERENCES}

1 Frid AH, Kreugel G, Grassi G, et al. New insulin delivery recommendations. Mayo Clin Proc 2016;91:1231-55.

2 Kalra S, Mithal A, Sahay R, et al. Indian injection technique study: injecting complications, education, and the health care professional. Diabetes Ther[Internet]2017:8:659-72.

Copyright 2017 BMJ Publishing Group. All rights reserved. For permission to reuse any of this content visit http://group.bmj.com/group/rights-licensing/permissions.

BMJ Case Report Fellows may re-use this article for personal use and teaching without any further permission.

Become a Fellow of BMJ Case Reports today and you can:

- Submit as many cases as you like

- Enjoy fast sympathetic peer review and rapid publication of accepted articles

- Access all the published articles

Re-use any of the published material for personal use and teaching without further permission

For information on Institutional Fellowships contact consortiasales@bmjgroup.com

Visit casereports.bmj.com for more articles like this and to become a Fellow 